Review

\title{
Clonal Expansion of T Cells in Abdominal Aortic Aneurysm: A Role for Doxycycline as Drug of Choice?
}

\author{
Albert M. Kroon and Jan-Willem Taanman * \\ Department of Clinical Neurosciences, Institute of Neurology, University College London, \\ London NW3 2PF, UK; E-Mail: amk@keab.nl \\ * Author to whom correspondence should be addressed; E-Mail: j.taanman@ucl.ac.uk; \\ Tel.: +44-7794-0500 (ext. 35354); Fax: +44-7472-6829.
}

Academic Editors: Jonathan Golledge and Joseph V. Moxon

Received: 7 November 2014 / Accepted: 5 February 2015 / Published: 18 May 2015

\begin{abstract}
Most reported studies with animal models of abdominal aortic aneurysm (AAA) and several studies with patients have suggested that doxycycline favourably modifies AAA; however, a recent large long-term clinical trial found that doxycycline did not limit aneurysm growth. Thus, there is currently no convincing evidence that doxycycline reduces AAA expansion. Here, we critically review the available experimental and clinical information about the effects of doxycycline when used as a pharmacological treatment for AAA. The view that AAA can be considered an autoimmune disease and the observation that AAA tissue shows clonal expansion of T cells is placed in the light of the well-known inhibition of mitochondrial protein synthesis by doxycycline. In $\mathrm{T}$ cell leukaemia animal models, this inhibitory effect of the antibiotic has been shown to impede $\mathrm{T}$ cell proliferation, resulting in complete tumour eradication. We suggest that the available evidence of doxycycline action on AAA is erroneously ascribed to its inhibition of matrix metalloproteinases (MMPs) by competitive binding of the zinc ion co-factor. Although competitive binding may explain the inhibition of proteolytic activity, it does not explain the observed decreases of MMP mRNA levels. We propose that the observed effects of doxycycline are secondary to inhibition of mitochondrial protein synthesis. Provided that serum doxycycline levels are kept at adequate levels, the inhibition will result in a proliferation arrest, especially of clonally expanding $\mathrm{T}$ cells. This, in turn, leads to the decrease of proinflammatory cytokines that are normally generated by these cells. The drastic change in cell type composition may explain the changes in MMP mRNA and protein levels in the tissue samples.
\end{abstract}


Keywords: abdominal aortic aneurysm (AAA); clonal expansion; doxycycline; drug target; matrix metalloproteinases; mitochondrial protein synthesis; T cells

\section{Introduction}

Abdominal aortic aneurysm (AAA) is characterised by a progressive localised weakening and dilatation of the abdominal aorta. AAA is a common and serious medical condition in elderly people, especially among men [1]. The 2013/2014 results of the National Health Service AAA Screening Programme suggested a $1.25 \%$ prevalence of AAA with a diameter larger than $3.0 \mathrm{~cm}$ in 65 -year-old men who had not had previous AAA surgery [2]. There is a high propensity to rupture when the aneurysm diameter reaches 5.0 to $5.5 \mathrm{~cm}$. The mortality associated with AAA rupture is about $70 \%$ [2,3]; the majority of patients will die before they reach the operating theatre due to massive internal bleeding. Small aneurysms are, however, not void of the risk of rupture either [4].

Surgical repair is currently the only available treatment option for AAA. There are two scenarios for surgical intervention: traditional open repair and endovascular repair [5-7]. Small, asymptomatic AAAs are normally managed conservatively by regular monitoring. Current guidelines recommend surgical repair when the aneurysm diameter is expanding by more than $1 \mathrm{~cm}$ per year or is larger than $5.5 \mathrm{~cm}$. Nevertheless, conservative management may remain the preferred choice for patients at high risk of mortality during surgical treatment.

\section{Pharmacological Interventions for AAA}

A pharmacological treatment that arrests or slows the progression of AAAs, thus reducing the pressure for surgical intervention, would have major advantages for patients as well as the healthcare system. Various drug targets have been considered and numerous attempts to affect these targets have been reported. An overview of these studies is given in Table 1. The advances in mechanistic studies that provide insights into these potential pharmacological treatments of AAA have been reviewed recently [8-10]. The authors conclude that, to date, there is no proven pharmacological intervention available for preventing the expansion and rupture of AAA. The observation reported recently that aneurysmal lesions contain clonally expanded $\mathrm{T}$ cells [11] prompted us to compare the available evidence for the reported inhibitory effects of doxycycline on AAA with our own experiences in tumour systems $[12,13]$.

\section{Doxycycline and AAA}

In its initial stage, AAA is an inflammatory condition. Roles for B and T lymphocytes have long been recognised in AAA disease [14-16]. This has led to the notion that AAA may be a specific antigen-driven $\mathrm{T}$ cell disease $[17,18]$ and attempts to characterise the antigens have been published [19]. In a recent review, treatment with the tetracycline antibiotic doxycycline was advocated as a non-invasive therapy for AAA, based on its inhibitory effects on matrix metalloproteinases (MMPs) [10]. A moderate change of MMP activity was confirmed in a clinical trial by Lindeman et al. [20] but their main observation concerned a significant reduction of the aortic wall neutrophil and cytotoxic $\mathrm{T}$ cell content. 
The recent finding by $\mathrm{Lu}$ et al. [11] that aneurysmal lesions contain clonally expanded $\mathrm{T}$ cells may indicate that Lindeman et al. [20] have actually observed the inhibitory effect of doxycycline on this expansion.

Table 1. Targets and pharmacological approaches for a conservative treatment of abdominal aortic aneurysm (AAA).

\begin{tabular}{lll}
\hline Targets & Pharmacological Approaches & References \\
\hline Neutrophils and other blood components & $\begin{array}{l}\text { Anti-neutrophil antibodies, } \\
\text { TNF- } \alpha \text { inhibition, mycophenolate }\end{array}$ & {$[21-28]$ this review } \\
\hline$\beta$-Adrenergic blockade & Propranolol & {$[29-33]$} \\
\hline Renin-angiotensin system & TGF- $\beta 1$, cyclosporine A & {$[22,24,28,34-47]$} \\
\hline Cholesterol metabolism & Various statins and proteases & {$[43,47-57]$} \\
\hline Phospholipid metabolism & $\begin{array}{l}\text { 5-LO inhibitors, cyclooxygenase-2 } \\
\text { inhibitors, EP4 inhibitors }\end{array}$ & {$[26,28,58-64]$} \\
\hline $\begin{array}{l}\text { Peroxisome proliferation-associated } \\
\text { receptor (PPAR) }\end{array}$ & Glitazones & {$[65,66]$} \\
\hline $\begin{array}{l}\text { Various proteases: cysteine proteases, } \\
\text { serine proteases, matrix metalloproteinases } \\
\text { (MMPs), elastase and others }\end{array}$ & $\begin{array}{l}\text { Calpain inhibitors, chymase } \\
\text { inhibitors, doxycycline, } \\
\text { azithromycin, rhoxithromycin }\end{array}$ & $\begin{array}{l}{[24,25,33,39,41,67-70]} \\
\text { this review }\end{array}$ \\
\hline
\end{tabular}

\section{Doxycycline and Inhibition of T Cell Clonal Expansion}

Mitochondria, which are descendants of $\alpha$-proteobacteria, are sensitive to antibacterial agents interfering with ribosomal function, such as doxycycline [71]. Our extensive in vitro and in vivo investigations on the cytostatic and cytocidic effects of doxycycline and some other tetracycline antibiotics, led us to the idea that inhibition of mitochondrial protein synthesis and the subsequent decrease of the mitochondrial energy-generating capacity is a key target to fight cancer [13]. Tumour growth can be defined as a form of clonal expansion. In a rat $\mathrm{T}$ cell leukaemia model, arrest of $\mathrm{T}$ cell proliferation through inhibition of mitochondrial protein synthesis by doxycycline has been demonstrated to lead to a total elimination of the tumour [72,73]. It is tempting to speculate that inhibition of mitochondrial protein synthesis is the primary effect of doxycycline in the experimental and clinical studies of AAA. The proposed mechanism is illustrated in Figure 1.

\section{Doxycycline and Inhibition of Matrix Metalloproteinases (MMPs)}

MMPs play a key role in the degradation of extracellular matrix in normal physiological processes, such as embryonic development and tissue remodelling, as well as in pathogenic mechanisms of, e.g., tumour metastasis, arthritis and the formation of AAA [74]. Most members of the MMP family are soluble enzymes, secreted as inactive proproteins, which are activated upon cleavage by extracellular proteinases. A subset of MMPs however, is anchored to the plasma membrane. One of the most widely studied membrane-type MMPs, MT1-MMP, participates in the turnover of various extracellular matrix components and the activation of secreted MMPs [75]. MT1-MMP was reported to have an important function in the macrophage-dependent destruction of the elastin fibre network during AAA formation [76]. The secreted MMP-2 (gelatinase A) and MMP-9 (gelatinase B) participate in the catalytic cleavage of 
extracellular gelatine and collagen. In addition, MMP-9 may also exert non-catalytic anti-apoptotic signalling effects [77]. Both MMP-2 and -9 are thought to be directly involved in AAA formation.

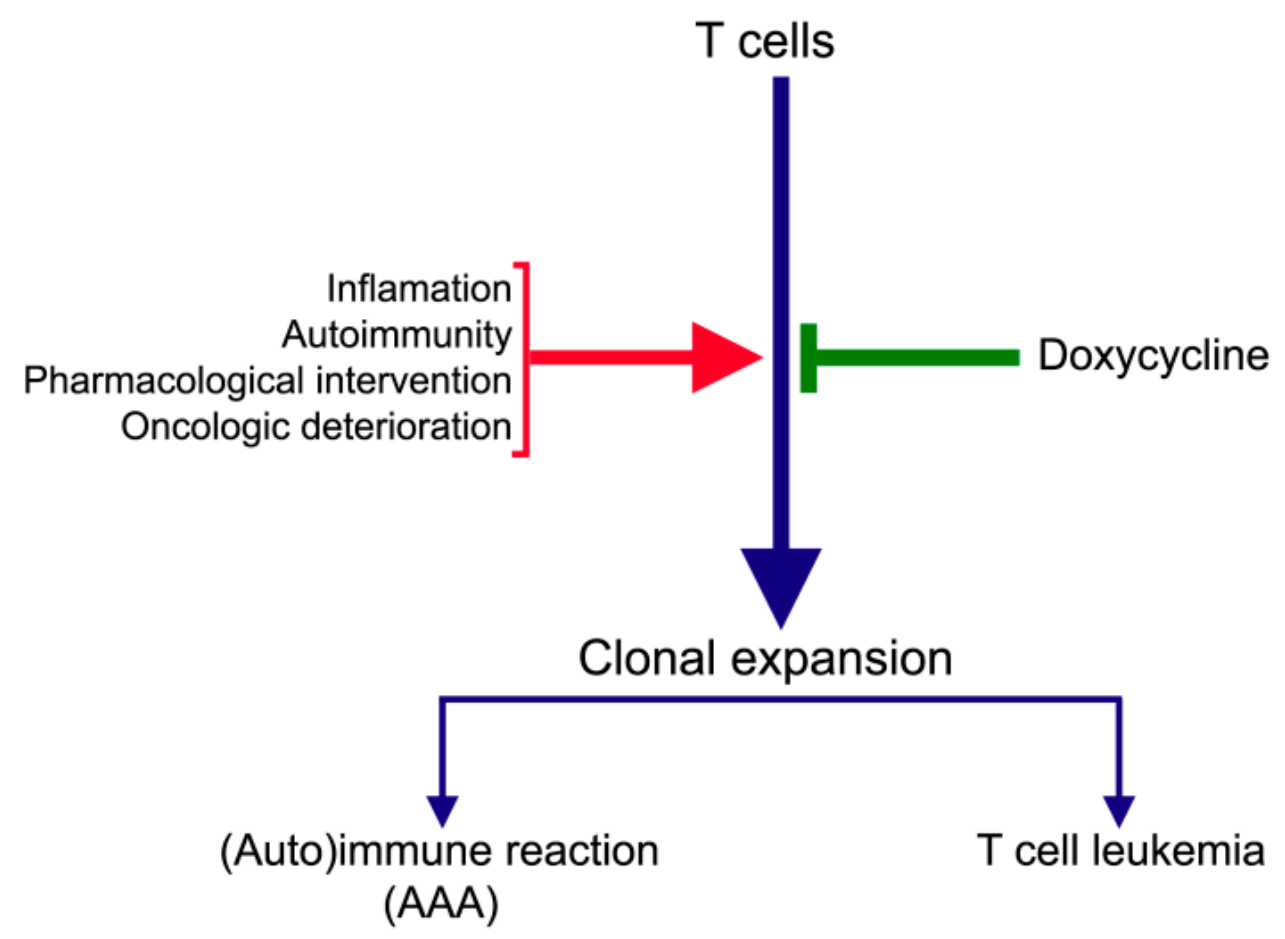

Figure 1. Schematic presentation of the possible causes of clonal expansion of $\mathrm{T}$ cells and the inhibition of doxycycline.

Tetracyclines are known to inhibit the activity of MMPs. This action has been attributed to their competitive binding of the catalytic zinc ion needed for MMP activity. Various natural tetracyclines and synthetic analogues have been tested as MMP inhibitors [78,79]. The aim of these studies was inhibition of the breakdown of the extracellular matrix that is thought to promote AAA formation and to facilitate metastasis of tumour cells [80]. The mechanism of action of MMP inhibition has been a rationale to design and produce tetracycline analogues void of antibacterial activity [78,81-83]. The fact that the exclusion of this activity might also cause loss of antimitochondrial activity has not been tested or has even been considered [78,83]. Non-antibacterial tetracycline analogues have been tested in a number of human cancer trials [84]. Unfortunately, so far, these studies yielded mostly disappointing results [78,79] and their poor clinical performances as anticancer agents have been stressed [85]. Curci et al. examined a series of 15 patients with AAA, of whom 8 patients were treated with an oral dose of $100 \mathrm{mg}$ of doxycycline twice a day for 7 days prior to surgery [86]. Total MMP enzyme activity measurements in post-operative aneurysm tissue failed to show differences.

\section{Doxycycline in Cell Culture and Animal Models of AAA}

Table 2 summarises the main aspects of the studies in which doxycycline has been tested as a possible drug in experimental animal models of AAA. The daily oral or subcutaneous dosage of doxycycline used in the in vivo studies varies from 10 to $100 \mathrm{mg} / \mathrm{kg}$. The current dosage for patients in standard doxycycline treatment is approximately 1.5 or $3 \mathrm{mg} / \mathrm{kg}$; however, not the dosage is critical but the serum 
levels that are reached. These are, unfortunately, lacking in most studies. Only Prall et al. showed that their regimes for humans and mice gave comparable blood levels [87].

Doxycycline has been shown to effectively inhibit AAA formation in most reported animal studies (Table 2; [88]). Furthermore, a delay of aneurysm rupture by doxycycline has been demonstrated in a mouse model of Marfan syndrome, a genetic connective tissue disorder [89]. These effects have been ascribed to a reduction of MMP-9 activity with a preservation of elastin in the extracellular matrix [90]. In cultured THP-1 monocytes, stimulated with phorbol ester, decreased expression of MMP-9 mRNA and proprotein have been observed after doxycycline treatment [86]. Even so, in their review of 2008, Baxter et al. concluded that additional studies are needed to clarify the role of doxycycline in the progression of aneurysmal disease [8]. 
Table 2. Effect of doxycycline in studies of AAA animal models.

\begin{tabular}{|c|c|c|c|c|c|c|c|c|c|}
\hline \multirow{2}{*}{$\begin{array}{c}\text { Publication } \\
\text { 1st Author } \\
\text { (Year) } \\
\end{array}$} & \multicolumn{3}{|c|}{ Doxycycline } & \multirow[b]{2}{*}{ No. of Animals } & \multicolumn{4}{|c|}{ Study Parameters } & \multirow[b]{2}{*}{ Effect } \\
\hline & Ref. & Dosage & Serum Level & & Type & Duration & Methods & Outcomes & \\
\hline $\begin{array}{c}\text { Petrinec, D. } \\
(1996) \\
\end{array}$ & {$[90]$} & $12.5 \mathrm{mg}$ bid, s.c. & No data & 48 rats & $\mathrm{PC}$ & $\leq 14$ days & el.-ind. AAA & $\begin{array}{c}\text { MMP exp.; } \\
\text { MMP act.; expansion }\end{array}$ & + \\
\hline $\begin{array}{c}\text { Boyle, J.R. } \\
\text { (1998) }\end{array}$ & {$[91]$} & 1 and $10 \mu \mathrm{g} / \mathrm{mL}$ & NA & 8 porcine samples & In vitro & 13 days & el.-ind. AAA & MMP exp.; MMP act & + \\
\hline $\begin{array}{c}\text { Curci, J.A. } \\
(1998)\end{array}$ & {$[92]$} & n.s., s.c. & No data & 52 rats & Open controlled & 7 days & el.-ind. AAA & $\begin{array}{c}\text { MMP exp.; } \\
\text { MMP act.; expansion }\end{array}$ & + \\
\hline $\begin{array}{c}\text { Prall, A.K. } \\
(2002)\end{array}$ & {$[87]$} & $\begin{array}{c}10,50,100 \mathrm{mg} / \mathrm{kg} / \mathrm{d} \\
\text { in d.w. }\end{array}$ & $\begin{array}{c}1.4,2.7 \\
11.9 \mu \mathrm{g} / \mathrm{mL}\end{array}$ & n.s. (mice) & Open PC & 10 weeks & el.-ind. AAA & MMP exp.; expansion & + \\
\hline $\begin{array}{c}\text { Manning, M.W. } \\
\text { (2003) }\end{array}$ & {$[93]$} & $30 \mathrm{mg} / \mathrm{kg} / \mathrm{d}$ in d.w. & No data & $\begin{array}{c}60 \text { mice } \\
\text { (hyperlipidemic) } \\
\end{array}$ & $\mathrm{PC}$ & 5 weeks & ang. II-ind. AAA & Expansion & + \\
\hline $\begin{array}{l}\text { Sho, E. } \\
(2004)\end{array}$ & [94] & $\begin{array}{c}60 \mathrm{mg} / \mathrm{kg} / \mathrm{d} \text {, s.c.; } \\
1.5 \mathrm{mg} / \mathrm{kg} / \mathrm{d} \text { via infusion }\end{array}$ & No data & n.s. (rats) & PC Controlled & 14 days & $\begin{array}{c}\text { el.-ind. AAA; } \\
\text { periaortic infusion } \\
\end{array}$ & $\begin{array}{c}\text { MMP exp.; expansion; } \\
\text { macrophage density }\end{array}$ & + \\
\hline \multirow[b]{2}{*}{$\begin{array}{l}\text { Bartoli, M.A. } \\
\text { (2006) }\end{array}$} & \multirow[b]{2}{*}{ [95] } & $\begin{array}{l}100 \mathrm{mg} / \mathrm{kg} / \mathrm{d} \\
\text { systemic p.o. }\end{array}$ & $0.33 \mu \mathrm{g} / \mathrm{mL}$ & n.s. (mice) & Open comparative & 14 days & el.-ind. AAA & Expansion & + \\
\hline & & $\begin{array}{l}\leq 1 \mathrm{mg} / \mathrm{kg} / \mathrm{d} \text { via } \\
\text { local infusion }\end{array}$ & $5.6-7.8 \mathrm{ng} / \mathrm{mL}$ & n.s. (mice) & Open comparative & 14 days & $\begin{array}{c}\text { el.-ind. AAA; } \\
\text { localised infusion with } \\
\text { osmotic minipump }\end{array}$ & Expansion & + \\
\hline $\begin{array}{c}\text { Xiong, W. } \\
(2008)\end{array}$ & [89] & $100 \mathrm{mg} / \mathrm{kg} / \mathrm{d}$ in d.w. & No data & 48 mice & Open PC & $\begin{array}{l}6 \text { weeks }+ \\
\text { follow-up }\end{array}$ & Marfan syndrome & Survival & + \\
\hline Xie, X. (2012) & {$[96]$} & $100 \mathrm{mg} / \mathrm{kg} / \mathrm{d}$ in d.w. & $2.3 \pm 0.6 \mu \mathrm{g} / \mathrm{mL}$ & 25 mice & $\mathrm{PC}$ & 8 weeks & ang. II-ind. AAA & Expansion & - \\
\hline $\begin{array}{l}\text { Sivaraman, B. } \\
\text { (2013) }\end{array}$ & {$[97]$} & $\begin{array}{c}2 \%, 5 \% \text { and } 10 \% \\
\text { in nanoparticles }\end{array}$ & NA & $\begin{array}{c}\text { n.s. } \\
\text { (rat AAA tissue) }\end{array}$ & In vitro & $\begin{array}{l}\text { Rats: } 2 \text { weeks } \\
\text { TC: } 3 \text { weeks }\end{array}$ & el.-ind. AAA & MMP exp.; MMP act & + \\
\hline
\end{tabular}

Abbreviations: ang. II-ind. AAA, angioptensin II-induced AAA; bid, twice daily; d.w., drinking water; el.-ind. AAA, elastase-induced AAA; MMP exp., MMP gene expression; MMP act, MMP enzyme activity; NA, not applicable; n.s., not specified; PC, placebo-controlled; p.o., oral; s.c., subcutaneous; TC, tissue culture. 
Improved efficacy on juxta-aortic delivery of doxycycline has been shown in rats by Sho et al. with the aid of a novel prototype infusion system [94]. To avoid dose-related side effects of systemic administration of doxycycline, localised administration with osmotic mini-pumps has been applied in mice by Bartoli et al. [95]. In their experiments, the doxycycline level in aortic tissue was extremely low as compared to those in other studies. Despite of the low concentration, the authors claimed that the localised administration suppressed aortic dilatation. The development of doxycycline formulations with nanoparticles may offer another approach for localised, controlled and sustained release in the future [97].

As mentioned above, MMP-9 may prevent apoptosis in a non-catalytic manner [77]. This deserves further attention since apoptosis would have a healing effect on AAA. Induction of apoptosis by tetracyclines has been reported [98]. In this context, an in vivo investigation with doxycycline in mice bearing an experimentally induced AAA should be mentioned [87]. In this study, doxycycline serum levels were measured after 5 weeks of treatment. The levels matched those obtained with standard doses in patients ( 2 to $9 \mu \mathrm{g} / \mathrm{mL}$ of serum) and are within the range of an antimitochondrial effect [13]. Although a decrease in aortic diameter and expression of active MMP-9 and its proprotein were shown following doxycycline treatment, the authors did not investigate an antimitochondrial effect and this can, therefore, not be excluded as the primary cause of the aneurysm growth inhibition.

While in most animal studies doxycycline was administered prior to the initiation of the disease, Xie et al. [96] started administration in mice 28 days after induction of AAA. This scenario may be more relevant to patients, where a treatment for established AAA is needed. During the 8 weeks of treatment, expansion rates of AAAs were not reduced, suggesting that doxycycline is not effective in this mouse model of established AAA [96].

\section{Doxycycline in Clinical Trials of AAA Patients}

Table 3 sums up the results of investigations in patients. In most studies, a fixed oral dose of $100 \mathrm{mg}$ twice daily was used. In the oldest study, published in 1999 [99], tissue from five patients treated with doxycycline was compared with that from five untreated patients. MMP-2 and -9 mRNA levels in aneurysmal tissue obtained at the time of surgery were strongly reduced by preoperative treatment as compared to the untreated disease controls. Although the study of 15 patients by Curci et al. [86], mentioned in paragraph 5, failed to show differences in MMP-9 enzyme activity, doxycycline-treated patients did show reduced levels of MMP-9 mRNA and protein, as well as a suppressed modification of MMP-2 proprotein in macrophages. Promising results were also obtained in a prospective, double-blind, placebo-controlled pilot study with 32 patients by Morosin et al. [100]. The active group received oral doses of $150 \mathrm{mg}$ of doxycycline daily for a period of 3 months. The aneurysm expansion rate in the active group was significantly lower than that in the placebo group. In a similar-sized prospective, double-blind, placebo-controlled, phase-II, multicentre study, no significant change was seen in the aneurysm expansion rate but prolonged administration of doxycycline was associated with a gradual reduction in plasma MMP-9 levels; however, enzyme activities were not measured [101]. 
Table 3. Effect of doxycycline in clinical trials with AAA patients.

\begin{tabular}{|c|c|c|c|c|c|c|c|c|}
\hline \multicolumn{2}{|c|}{ Publication } & \multicolumn{2}{|c|}{ Doxycycline } & \multicolumn{5}{|c|}{ Study Parameters } \\
\hline $\begin{array}{c}\text { 1st Author } \\
\text { (Year) }\end{array}$ & Ref. & Dosage & Serum Level & $\begin{array}{c}\text { No. of } \\
\text { Patients }\end{array}$ & Type & Duration & Outcomes & Effect \\
\hline $\begin{array}{c}\text { Thompson, R.W. } \\
\text { (1999) }\end{array}$ & [99] & $100 \mathrm{mg} 2 \times \mathrm{dd}$ & No data & 10 & Open & 7 days & Small AAA & + \\
\hline $\begin{array}{l}\text { Curci, J.A. } \\
(2000)\end{array}$ & {$[86]$} & $100 \mathrm{mg} 2 \times \mathrm{dd}$ & No data & 15 & $\begin{array}{c}\text { Open } \\
\text { controlled }\end{array}$ & 7 days & MMP exp. & + \\
\hline $\begin{array}{l}\text { Mosorin, M. } \\
\text { (2001) }\end{array}$ & {$[100]$} & $150 \mathrm{mg} 1 \times \mathrm{dd}$ & No data & 32 & $\mathrm{DBPC}$ & $\begin{array}{r}3 \text { months } \\
+15 \text { months } \\
\end{array}$ & $\begin{array}{c}\text { Expansion, } 15 \text { months } \\
\text { surveillance }\end{array}$ & + \\
\hline $\begin{array}{l}\text { Baxter, B.T. } \\
\text { (2002) }\end{array}$ & {$[101]$} & $100 \mathrm{mg} 2 \times \mathrm{dd}$ & $4.62 \mu \mathrm{g} / \mathrm{mL}$ & 36 & $\begin{array}{c}\text { DBPC } \\
\text { Phase II }\end{array}$ & 6 months & MMP exp.; expansion & $+;-$ \\
\hline $\begin{array}{l}\text { Prall, A.K. } \\
\text { (2002) }\end{array}$ & {$[87]$} & $100 \mathrm{mg} 2 \times \mathrm{dd}$ & $1.8-9.2 \mu \mathrm{g} / \mathrm{mL}$ & n.s. & Open & 6 months & $\begin{array}{l}\text { Serum levels in range of those } \\
\text { of mice in comparative study } \\
\text { (see Table 2) }\end{array}$ & + \\
\hline $\begin{array}{c}\text { Brown, D.L. } \\
(2004)\end{array}$ & {$[102]$} & $20 \mathrm{mg} 2 \times \mathrm{dd}$ & No data & 50 & $\mathrm{DBPC}$ & 6 months & $\begin{array}{c}\text { Acute coronary } \\
\text { syndromes, MMP exp. }\end{array}$ & No AAA \\
\hline $\begin{array}{l}\text { Hackmann, A.E. } \\
(2008)\end{array}$ & {$[68]$} & $100 \mathrm{mg} 2 \times \mathrm{dd}$ & No data & 44 & $\mathrm{DBPC}$ & 6 months & MMP exp.; expansion & $+;+$ \\
\hline $\begin{array}{c}\text { Lindeman, J.H.N. } \\
\text { (2009) }\end{array}$ & {$[20]$} & $\begin{array}{c}50,100,300 \mathrm{mg} \\
1 \times \mathrm{dd} \\
\end{array}$ & No data & 60 & $\begin{array}{c}\mathrm{SB} \\
\text { controlled }\end{array}$ & 2 weeks & $\begin{array}{l}\text { MMP exp.; MMP act; } \\
\text { leukocyte content }\end{array}$ & $+; \pm ;+$ \\
\hline $\begin{array}{l}\text { Meijer, C.A. } \\
(2013)\end{array}$ & {$[103]$} & $100 \mathrm{mg} 1 \times \mathrm{dd}$ & No data & 286 & DBPC & 18 months & Expansion & - \\
\hline $\begin{array}{l}\text { Kurosawa, K. } \\
\text { (2013) }\end{array}$ & {$[10,104]$} & $100 \mathrm{mg} 2 \times \mathrm{dd}$ & No data & 248 & DBPC & $\begin{array}{l}2-3 \text { years } \\
\text { (planned) }\end{array}$ & Study in progress & unkown \\
\hline
\end{tabular}

Abbreviations: $1 \times \mathrm{dd}$, once daily; $2 \times \mathrm{dd}$, twice daily; DBPC, double-blind placebo-controlled; MMP act., MMP enzyme activity; MMP exp., MMP gene expression; n.s., not specified; SB, single (investigator) blinded. 
Although the study does not concern AAA but acute coronary syndromes, it is interesting to mention the paper by Brown et al., who performed a prospective, double-blind, placebo-controlled pilot study of 50 patients, in which the active group was treated with an oral dose of $20 \mathrm{mg}$ of doxycycline twice daily for a period of 6 months [102]. This relatively low dose, described as "subantimicrobial dose" [105], was chosen to exclude an effect on Chlamydia pneumoniae that otherwise might have interfered with the primary experimental goal. Pro-MMP-9 activity, but not MMP-2 activity, was decreased after 6 months [102]. Unfortunately, no data were included on the course and level of doxycycline in serum. For in vivo experiments it is important to check if the dose used is not only subantimicrobial but also "subantimitochondrial". In view of the half-life of doxycycline in humans, a cumulative effect remains conceivable [106]. It might well be that 20 or $50 \mathrm{mg}$ twice daily gives a result comparable with $100 \mathrm{mg}$ twice daily; the latter dose is acceptable however, based on experience with the treatment of bacterial infections and in some of the studies cited here. A serum level between 2 and $5 \mu \mathrm{g} / \mathrm{mL}$, the range of the antimitochondrial action [13], can certainly be reached at a dose of $20 \mathrm{mg}$ twice daily, assuming a half-life of $18 \mathrm{~h}$ [107].

Hackmann et al. [68] carried out a double-blind, placebo-controlled trial of 44 patients after endoluminal aneurysm repair. After 6 months of treatment with placebo or $100 \mathrm{mg}$ of doxycycline twice daily, plasma MMP-9 levels were decreased significantly below baseline in the doxycycline group, while there was a non-significant increase in the placebo group. Moreover, based on the endograft used, doxycycline treatment resulted in greater reductions in maximum aortic diameter than placebo treatment.

Recently a trial assessing the efficacy of $100 \mathrm{mg}$ doxycycline daily in 286 patients with small AAAs was reported [103]. This study included approximately 8 times the number of patients involved in previous small positive trials (Table 3). The investigators reported no benefit of doxycycline administered at this dose over 18 months; in fact, AAA growth was significantly greater in patients randomised to the active agent [103]. The dose of doxycycline used in this recent trial was less than in a number of previous investigations [86,99-101]. The dose of doxycycline chosen was based on a previous investigation in which the drug was assessed in 60 patients with large AAAs awaiting open aortic surgery [20]. That study suggested that $100 \mathrm{mg}$ of doxycycline daily markedly reduced inflammation within the AAAs of patients randomised to the medication. The drug administration period was very short however at 2 weeks. It is conceivable that a single daily oral dose of $100 \mathrm{mg}$ of doxycycline is not sufficient to maintain adequate doxycycline serum levels for a prolonged period [108]. If the doxycycline serum levels drop too low during the day, then the suggested benefits of the drug outlined in this article may not be able to be realised. A large on-going trial is investigating the benefit of a larger daily dose of doxycycline in patients with small AAAs [10,104]. Overall however there is currently no convincing clinical data that doxycycline benefits patients with small AAAs.

\section{Direct and Indirect Effects of Doxycycline}

The question was raised recently if any of the pharmacological agents tested do really slow the progression of AAA [61]. Lu et al. conclude that there remain many undefined complexities regarding the mechanisms and their possible translational consequences in spite of an improved understanding [9]. As discussed in this review, several studies support doxycycline treatment of patients with pre-operative 
AAA or at high risk of mortality at surgical intervention; however, we strongly question the assumption that clinical improvement with doxycycline can be ascribed to direct inhibition of the expression of MMPs.

Although the ability of doxycycline to chelate zinc may explain the effect on MMP enzyme activity and, possibly, MMP protein levels through destabilisation of its structure, there is no explanation how doxycycline can have an effect on the MMP mRNA levels. Therefore, we postulate that the primary effect of doxycycline is based on its inhibition of mitochondrial protein synthesis, preventing clonal expansion of T-cells and possibly also other proliferating cells in AAA tissue, thus, indirectly, resulting in a decrease of proinflammatory cytokines, MMP-2 and MMP-9 that otherwise damage the vascular stroma $[9,28,41]$. Whilst there is no direct experimental evidence available that the observed effects of doxycycline on AAA are based on its inhibition of mitochondrial protein synthesis, the finding of $\mathrm{Lu}$ et al. [11] that aneurysmal lesions contain clonally expanded $\mathrm{T}$ cells combined with our own observations in cancer research that doxycycline results in a proliferation arrests of $\mathrm{T}$ cells through its inhibition of mitochondrial protein synthesis [72,73] lends strong support to our hypothesis. The resulting changes in cell type composition of the AAA tissue render quantification of mRNA and primary translation products unreliable. Hence, the measured effects of doxycycline on MMP expression are indirect because the antibiotic does not influence nuclear-cytosolic protein synthesis.

We hope that this critical review and our new hypothesis on the role of doxycycline as drug of choice in AAA will spur further research on the possible role of mitochondrial protein inhibition in the treatment of AAA. Although the recent, large, double-blind, placebo-controlled Dutch clinical trial found that a single daily dose of $100 \mathrm{mg}$ of doxycycline did not reduce aneurysm growth [103], we believe that further investigations are justified. A vital demand for success is a permanent serum level of doxycycline at a concentration that effectively inhibits mitochondrial protein synthesis; twice a day a moderate dose may suffice. Such a treatment scenario (100 mg twice daily), or even a higher dosage (200 mg twice daily), is regularly applied to patients with Lyme disease [109-111]. Measurement of peak wall stress may be a useful parameter to judge a significant contribution of doxycycline to a better prognosis for AAA [3]. A large on-going clinical trial with a doxycycline dose of $100 \mathrm{mg}$ twice daily, estimated to be completed June 2017, has been announced [10]. Surveillance of serum levels is, unfortunately, not included as secondary outcome [104].

\section{Acknowledgments}

We thank the Royal Free Charity for their continued support.

\section{Author Contributions}

Albert M. Kroon conceived the paper and wrote the first draft; and Jan-Willem Taanman contributed substantially to the final text, tables, figure and references of the paper.

\section{Conflicts of Interest}

The authors declare no conflict of interest. 


\section{References}

1. Lindholt, J.S. Abdominal aortic aneurysms. Dan. Med. Bull. 2010, 57, B4219.

2. NHS Abdominal Aortic Screening Programme. Available online: http://www.aaa.screening.nhs. uk/2013-14datareports (accessed on 28 November 2014).

3. Khosla, S.; Morris, D.R.; Moxon, J.V.; Walker, P.J.; Gasser, T.C.; Golledge, J. Meta-analysis of peak wall stress in ruptured, symptomatic and intact abdominal aortic aneurysms. Br. J. Surg. 2014, $101,1350-1357$.

4. Sweeting, M.J.; Thompson, S.G.; Brown, L.C.; Powell, J.T. Meta-analysis of individual patient data to examine factors affecting growth and rupture of small abdominal aortic aneurysms. Br. J. Surg. 2012, 99, 655-665.

5. Powell, J.T.; Brown, L.C.; Greenhalgh, R.M.; Thompson, S.G. The rupture rate of large abdominal aortic aneurysms: Is this modified by anatomical suitability for endovascular repair? Ann. Surg. 2008, 247, 173-179.

6. Lederle, F.A.; Freischlag, J.A.; Kyriakides, T.C.; Padberg, F.T., Jr.; Matsumura, J.S.; Kohler, T.R.; Lin, P.H.; Jean-Claude, J.M.; Cikrit, D.F.; Swanson, K.M.; et al. Outcomes following endovascular vs. open repair of abdominal aortic aneurysm: A randomized trial. JAMA 2009, 302, 1535-1542.

7. Antoniou, G.A.; Georgiadis, G.S.; Antoniou, S.A.; Pavlidis, P.; Maras, D.; Sfyroeras, G.S.; Georgakarakos, E.I.; Lazarides, M.K. Endovascular repair for ruptured abdominal aortic aneurysm confers an early survival benefit over open repair. J. Vasc. Surg. 2013, 58, 1091-1105.

8. Baxter, B.T.; Terrin, M.C.; Dalman, R.L. Medical management of small abdominal aortic aneurysms. Circulation 2008, 117, 1883-1889.

9. Lu, H.; Rateri, D.L.; Bruemmer, D.; Cassis, L.A.; Daugherty, A. Novel mechanisms of abdominal aortic aneurysms. Curr. Atheroscler. Rep. 2012, 14, 402-412.

10. Kurosawa, K.; Matsumura, J.S.; Yamanouchi, D. Current status of medical treatment for abdominal aortic aneurysm. Circ. J. 2013, 77, 2860-2866.

11. Lu, S.; White, J.V.; Lin, W.L.; Zhang, X.; Solomides, C.; Evans, K.; Ntaoula, N.; Nwaneshiudu, I.; Gaughan, J.; Monos, D.S.; et al. Aneurysmal lesions of patients with abdominal aortic aneurysm contain clonally expanded T cells. J. Immunol. 2014, 192, 4897-4912.

12. Kroon, A.M.; Taanman, J.W. Comment on "Aneurysmal lesions of patients with abdominal aortic aneurysm contain clonally expanded T cells”. J. Immunol. 2014, 193, 2041.

13. Kroon, A.M.; Taanman, J.W. Mitochondria and cancer: The Warburg fact. Chemotherapy 2014, 3,314 .

14. Shimizu, K.; Shichiri, M.; Libby, P.; Lee, R.T.; Mitchell, R.N. Th2-predominant inflammation and blockade of IFN- $\gamma$ signaling induce aneurysms in allografted aortas. J. Clin. Investig. 2004, 114, 300-308.

15. Uchida, H.A.; Kristo, F.; Rateri, D.L.; Lu, H.; Charnigo, R.; Cassis, L.A.; Daugherty, A. Total lymphocyte deficiency attenuates AngII-induced atherosclerosis in males but not abdominal aortic aneurysms in apoE deficient mice. Atherosclerosis 2010, 211, 399-403.

16. Yin, M.; Zhang, J.; Wang, Y.; Wang, S.; Bockler, D.; Duan, Z.; Xin, S. Deficient CD4 CD25 ${ }^{+} \mathrm{T}$ regulatory cell function in patients with abdominal aortic aneurysms. Arterioscler. Thromb. Vasc. Biol. 2010, 30, 1825-1831. 
17. Platsoucas, C.D.; Lu, S.; Nwaneshiudu, I.; Solomides, C.; Agelan, A.; Ntaoula, N.; Purev, E.; Li, L.P.; Kratsios, P.; Mylonas, E.; et al. Abdominal aortic aneurysm is a specific antigen-driven T cell disease. Ann. N. Y. Acad. Sci. 2006, 1085, 224-235.

18. Schirmer, M.; Duftner, C.; Seiler, R.; Dejaco, C.; Fraedrich, G. Abdominal aortic aneurysms: An underestimated type of immune-mediated large vessel arteritis? Curr. Opin. Rheumatol. 2006, $18,48-53$.

19. Platsoucas, C.D.; Oleszak, E.L. Human autoimmune diseases are specific antigen-driven T-cell diseases: Identification of the antigens. Immunol. Res. 2007, 38, 359-372.

20. Lindeman, J.H.N; Abdul-Hussien, H.; van Bockel, J.H.; Wolterbeek, R.; Kleemann, R. Clinical trial of doxycycline for matrix metalloproteinase-9 inhibition in patients with an abdominal aneurysm: Doxycycline selectively depletes aortic wall neutrophils and cytotoxic $\mathrm{T}$ cells. Circulation 2009, 119, 2209-2216.

21. Xiong, W.; MacTaggart, J.; Knispel, R.; Worth, J.; Persidsky, Y.; Baxter, B.T. Blocking TNF- $\alpha$ attenuates aneurysm formation in a murine model. J. Immunol. 2009, 183, 2741-2746.

22. Lindeman, J.H.N.; Rabelink, T.J.; van Bockel, J.H. Immunosuppression and the abdominal aortic aneurysm: Doctor Jekyll or Mister Hyde? Circulation 2011, 124, e463-e465.

23. Kimura, H.; Akutsu, N.; Shiomi, R.; Kohmura, E. Subarachnoid hemorrhage caused by ruptured intracranial fusiform aneurysm associated with microscopic polyangiitis. Neurol. Med. Chir. (Tokyo) 2012, 52, 495-498.

24. Shi, G.P.; Lindholt, J.S. Mast cells in abdominal aortic aneurysms. Curr. Vasc. Pharmacol. 2013, 11, 314-326.

25. Wang, Y.; Shi, G.P. Mast cell chymase and tryptase in abdominal aortic aneurysm formation. Trends Cardiovasc. Med. 2012, 22, 150-155.

26. Hansson, E.C.; Dellborg, M.; Lepore, V.; Jeppsson, A. Prevalence, indications and appropriateness of antiplatelet therapy in patients operated for acute aortic dissection: Associations with bleeding complications and mortality. Heart 2013, 99, 116-121.

27. Alsac, J.M.; Delbosc, S.; Rouer, M.; Journé, C.; Louedec, L.; Meilhac, O.; Michel, J.B. Fucoidan interferes with Porphyromonas gingivalis-induced aneurysm enlargement by decreasing neutrophil activation. J. Vasc. Surg. 2013, 57, 796-805.

28. Meng, X.; Yang, J.; Zhang, K.; An, G.; Kong, J.; Jiang, F.; Zhang, Y.; Zhang, C. Regulatory $\mathrm{T}$ cells prevent angiotensin II-induced abdominal aortic aneurysm in apolipoprotein $\mathrm{E}$ knockout mice. Hypertension 2014, 64, 875-882.

29. Leach, S.D.; Toole, A.L.; Stern, H.; DeNatale, R.W.; Tilson, M.D. Effect of $\beta$-adrenergic blockade on the growth rate of abdominal aortic aneurysms. Arch. Surg. 1988, 123, 606-609.

30. Gadowski, G.R.; Pilcher, D.B.; Ricci, M.A. Abdominal aortic aneurysm expansion rate: Effect of size and $\beta$-adrenergic blockade. J. Vasc. Surg. 1994, 19, 727-731.

31. Lindholt, J.S.; Henneberg, E.W.; Juul, S.; Fasting, H. Impaired results of a randomised double blinded clinical trial of propranolol versus placebo on the expansion rate of small abdominal aortic aneurysms. Int. Angiol. 1999, 18, 52-57.

32. Guessous, I.; Periard, D.; Lorenzetti, D.; Cornuz, J.; Ghali, W.A. The efficacy of pharmacotherapy for decreasing the expansion rate of abdominal aortic aneurysms: A systematic review and meta-analysis. PLOS ONE 2008, 3, e1895. 
33. Rughani, G.; Robertson, L.; Clarke, M. Medical treatment for small abdominal aortic aneurysms. Cochrane Database Syst. Rev. 2012, doi:10.1002/14651858.CD009536.pub2.

34. Liao, S.; Miralles, M.; Kelley, B.J.; Curci, J.A.; Borhani, M.; Thompson, R.W. Suppression of experimental abdominal aortic aneurysms in the rat by treatment with angiotensin-converting enzyme inhibitors. J. Vasc. Surg. 2001, 33, 1057-1064.

35. Neptune, E.R.; Frischmeyer, P.A.; Arking, D.E.; Myers, L.; Bunton, T.E.; Gayraud, B.; Ramirez, F.; Sakai L.Y.; Dietz, H.C. Dysregulation of TGF- $\beta$ activation contributes to pathogenesis in Marfan syndrome. Nat. Genet. 2003, 33, 407-411.

36. Habashi, J.P.; Judge, D.P.; Holm, T.M.; Cohn, R.D.; Loeys, B.L.; Cooper, T.K.; Myers, L.; Klein, E.C.; Liu, G.; Calvi, C.; et al. Losartan, an AT1 antagonist, prevents aortic aneurysm in a mouse model of Marfan syndrome. Science 2006, 312, 117-121.

37. Daugherty, A.; Manning, M.W.; Cassis, L.A. Angiotensin II promotes atherosclerotic lesions and aneurysms in apolipoprotein E-deficient mice. J. Clin. Investig. 2000, 105, 1605-1612.

38. Sweeting, M.J.; Thompson, S.G.; Brown, L.C.; Greenhalgh, R.M.; Powell, J.T. Use of angiotensin converting enzyme inhibitors is associated with increased growth rate of abdominal aortic aneurysms. J. Vasc. Surg. 2010, 52, 1-4.

39. Subramanian, V.; Uchida, H.A.; Ijaz, T.; Moorleghen, J.J.; Howatt, D.A.; Balakrishnan, A. Calpain inhibition attenuates angiotensin II-induced abdominal aortic aneurysms and atherosclerosis in low-density lipoprotein receptor-deficient mice. J. Cardiovasc. Pharmacol. 2012, 59, 66-76.

40. Lu, H.; Rateri, D.L.; Bruemmer, D.; Cassis, L.A.; Daugherty, A. Involvement of the renin-angiotensin system in abdominal and thoracic aortic aneurysms. Clin. Sci. (Lond.) 2012, 123, 531-543.

41. Takai, S.; Jin, D.; Miyazaki, M. Multiple mechanisms for the action of chymase inhibitors. J. Pharmacol. Sci. 2012, 118, 311-316.

42. Groenink, M.; den Hartog, A.W.; Franken, R.; Radonic, T.; de Waard, V.; Timmermans, J.; Scholte, A.J.; van den Berg, M.P.; Spijkerboer, A.M.; Marquering, H.A.; et al. Losartan reduces aortic dilatation rate in adults with Marfan syndrome: A randomized controlled trial. Eur. Heart J. 2013, 34, 3491-3500.

43. Piechota-Polanczyk, A.; Demyanets, S.; Nykonenko, O.; Huk, I.; Mittlboeck, M.; Domenig, C.M.; Neumayer, C.; Wojta, J.; Nanobachvili, J.; Klinger, M. Decreased tissue levels of cyclophilin A, a cyclosporine A target and phospho-ERK1/2 in simvastatin patients with abdominal aortic aneurysm. Eur. J. Vasc. Endovasc. Surg. 2013, 45, 682-688.

44. Zhou, H.F.; Yan, H.; Bertram, P.; Hu, Y.; Springer, L.E.; Thompson, R.W.; Curci, J.A.; Hourcade, D.E.; Pham C.T. Fibrinogen-specific antibody induces abdominal aortic aneurysm in mice through complement lectin pathway activation. Proc. Natl. Acad. Sci. USA 2013, 110, E4335-E4344.

45. Sharif, M.A.; McDowell, D.A.; Badger, S.A. Chlamydia pneumoniae antibodies and C-reactive protein levels in patients with abdominal aortic aneurysms. Sci. World J. 2013, doi:org/10.1155/ 2013/212450.

46. Wheeler, J.B.; Ikonomidis, J.S.; Jones, J.A. Connective tissue disorders and cardiovascular complications: The indomitable role of transforming growth factor- $\beta$ signaling. Adv. Exp. Med. Biol. 2014, 802, 107-127. 
47. Takahashi, K.; Matsumoto, Y.; Doe, Z.; Kanazawa, M.; Satoh, K.; Shimizu, T.; Sato, A.; Fukumoto, Y.; Shimokawa, H. Combination therapy with atorvastatin and amlodipine suppresses angiotensin II-induced aortic aneurysm formation. PLoS ONE 2013, 8, e72558.

48. Steinmetz, E.F.; Buckley, C.; Shames, M.L.; Ennis, T.L.; Vanvickle-Chavez, S.J.; Mao, D.; Goeddel, L.A.; Hawkins, C.J.; Thompson, R.W. Treatment with simvastatin suppresses the development of experimental abdominal aortic aneurysms in normal and hypercholesterolemic mice. Ann. Surg. 2005, 241, 92-101.

49. Schouten, O.; van Laanen, J.H.H.; Boersma, E.; Vidakovic, R.; Feringa, H.H.H.; Dunkelgrün, M.; Bax, J.J.; Koning, J.; van Urk, H.; Poldermans, D. Statins are associated with a reduced infrarenal abdominal aortic aneurysm growth. Eur. J. Vasc. Endovasc. Surg. 2006, 32, 21-26.

50. Evans, J.; Powell, J.T.; Schwalbe, E.; Loftus, I.M.; Thompson, M.M. Simvastatin attenuates the activity of matrix metalloprotease-9 in aneurysmal aortic tissue. Eur. J. Vasc. Endovasc. Surg. 2007, 34, 302-303.

51. Takagi, H.; Matsui, M.; Umemoto, T. A meta-analysis of clinical studies of statins for prevention of abdominal aortic aneurysm expansion. J. Vasc. Surg. 2010, 52, 1675-1681.

52. Takagi, H.; Yamamoto, H.; Iwata, K.; Goto, S.; Umemoto, T. Effects of statin therapy on abdominal aortic aneurysm growth: A meta-analysis and meta-regression of observational comparative studies. Eur. J. Vasc. Endovasc. Surg. 2012, 44, 287-292.

53. Mastoraki, S.T.; Toumpoulis, I.K.; Anagnostopoulos, C.E.; Tiniakos, D.; Papalois, A.; Chamogeorgakis, T.P.; Angouras, D.C.; Rokkas, C.K. Treatment with simvastatin inhibits the formation of abdominal aortic aneurysms in rabbits. Ann. Vasc. Surg. 2012, 26, 250-258.

54. Piechota-Polanczyk, A.; Goraca, A.; Demyanets, S.; Mittlboeck, M.; Domenig, C.; Neumayer, C.; Wojta, J.; Nanobachvili, J.; Huk, I.; Klinger, M. Simvastatin decreases free radicals formation in the human abdominal aortic aneurysm wall via NF-кB. Eur. J. Vasc. Endovasc. Surg. 2012, 44, 133-137.

55. Van der Meij, E.; Koning, G.G.; Vriens, P.W.; Peeters, M.F.; Meijer, C.A.; Kortekaas, K.E.; Dalman, R.L.; van Bockel, J.H.; Hanemaaijer, R.; Kooistra, T.; et al. A clinical evaluation of statin pleiotropy: Statins selectively and dose-dependently reduce vascular inflammation. PLoS ONE 2013, 8, e53882.

56. Houdek, K.; Moláček, J.; Třeška, V.; Križkova, V.; Eberlová, L.; Boudová, L.; Nedorost, L.; Tolinger, P.; Kočová, J.; Kobr, J.; et al. Focal histopathological progression of porcine experimental abdominal aortic aneurysm is mitigated by atorvastatin. Int. Angiol. 2013, 32, 291-306.

57. Twine, C.P.; Williams, I.M. Comment on: "Effects of statin therapy on abdominal aortic aneurysm growth: A meta-analysis and meta-regression of observational comparative studies". Eur. J. Vasc. Endovasc. Surg. 2013, 45, 98.

58. Kristo, F.; Hardy, G.J.; Anderson, T.J.; Sinha, S.; Ahluwalia, N.; Lin, A.Y.; Passeri J.; Scherrer-Crosbie, M.; Gerszten, R.E. Pharmacological inhibition of BLT1 diminishes early abdominal aneurysm formation. Atherosclerosis 2010, 210, 107-113.

59. Ghoshal, S.; Loftin, C.D. Cyclooxygenase-2 inhibition attenuates abdominal aortic aneurysm progression in hyperlipidemic mice. PLOS ONE 2012, 7, e44369. 
60. Mukherjee, K.; Gitlin, J.M.; Loftin, C.D. Effectiveness of cyclooxygenase-2 inhibition in limiting abdominal aortic aneurysm progression in mice correlates with a differentiated smooth muscle cell phenotype. J. Cardiovasc. Pharmacol. 2012, 60, 520-529.

61. Samson, R. Can pharmacologic agents slow abdominal aortic aneurysm growth? Semin. Vasc. Surg. 2012, 25, 25-28.

62. Scully, M.; Gang, C.; Condron, C.; Bouchier-Hayes, D.; Cunningham, A.J. Protective role of cyclooxygenase (COX)-2 in experimental lung injury: Evidence of a lipoxin A4-mediated effect. J. Surg. Res. 2012, 175, 176-184.

63. Yokoyama, U.; Ishiwata, R.; Jin, M.H.; Kato, Y.; Suzuki, O.; Jin, H.; Ichikawa, Y.; Kumagaya, S.; Katayama, Y.; Fujita, T.; et al. Inhibition of EP4 signaling attenuates aortic aneurysm formation. PLoS ONE 2012, 7, e36724.

64. Duftner, C.; Seiler, R.; Dejaco, C.; Chemelli-Steingruber, I.; Schennach, H.; Klotz, W.; Rieger, M.; Herold, M.; Falkensammer, J.; Fraedrich, G.; et al. Antiphospholipid antibodies predict progression of abdominal aortic aneurysms. PLoS ONE 2014, 9, e99302.

65. Kadowaki, T. PPAR $\gamma$ agonist and antagonist. Nihon Yakurigaku. Zasshi. 2001, 118, 321-326.

66. Torsney, E.; Pirianov, G.; Cockerill, G.W. Diabetes as a negative risk factor for abdominal aortic aneurysm-Does the disease aetiology or the treatment provide the mechanism of protection? Curr. Vasc. Pharmacol. 2013, 11, 293-298.

67. Vammen, S.; Lindholt, J.S.; Ostergaard, L.; Fasting, H.; Henneberg, E.W. Randomized double-blind controlled trial of roxithromycin for prevention of abdominal aortic aneurysm expansion. Br. J. Surg. 2001, 88, 1066-1072.

68. Hackmann, A.E.; Rubin, B.G.; Sanchez, L.A.; Geraghty, P.A.; Thompson, R.W.; Curci, J.A. A randomized, placebo-controlled trial of doxycycline after endoluminal aneurysm repair. J. Vasc. Surg. 2008, 48, 519-526.

69. Karlsson, L.; Gnarpe, J.; Bergqvist, D.; Lindbäck, J.; Pärsson, H. The effect of azithromycin and Chlamydophilia pneumonia infection on expansion of small abdominal aortic aneurysms-A prospective randomized double-blind trial. J. Vasc. Surg. 2009, 50, $23-29$.

70. Wágsäter, D.; Johansson, D.; Fontaine, V.; Vorkapic, E.; Backlund, A.; Razuvaev, A.; Mayranpaa, M.I.; Hjerpe, C.; Caidahl, K.; Hamsten, A.; et al. Serine protease inhibitor A3 in atherosclerosis and aneurysm disease. Int. J. Mol. Med. 2012, 30, 288-294.

71. Borst, P.; Grivell, L.A. Mitochondrial ribosomes. FEBS Lett. 1971, 13, 73-88.

72. Van den Bogert, C.; Dontje, B.H.; Kroon, A.M. The antitumour effect of doxycycline on a T-cell leukaemia in the rat. Leuk. Res. 1985, 9, 617-623.

73. Van den Bogert, C.; Dontje, B.H.; Kroon, A.M. Doxycycline in combination chemotherapy of a rat leukemia. Cancer Res. 1988, 48, 6686-6690.

74. Amălinei, C.; Căruntu, I.D.; Giuşcă, S.E.; Bălan, R.A. Matrix metalloproteinases involvement in pathologic conditions. Rom. J. Morphol. Embryol. 2010, 51, 215-228.

75. Remacle, A.; Murphy, G.; Roghi, C. Membrane type 1-matrix metalloproteinase (MT1-MMP) is internalised by two different pathways and is recycled to the cell surface. J. Cell Sci. 2003, 116, 3965-3916. 
76. Xiong, W.; Knispel, R.; MacTaggart, J.; Greiner, T.C.; Weiss, S.J.; Baxter, B.T. Membrane-type 1 matrix metalloproteinase regulates macrophage-dependent elastolytic activity and aneurysm formation in vivo. J. Biol. Chem. 2009, 284, 1765-1771.

77. Vandooren, J.; van den Steen, P.E.; Opdenakker, G. Biochemistry and molecular biology of gelatinase B or matrix metalloproteinase-9 (MMP-9): The next decade. Crit. Rev. Biochem. Mol. Biol. 2013, 48, 222-272.

78. Acharya, M.R.; Venitz, J.; Figg, W.D.; Sparreboom, A. Chemically modified tetracyclines as inhibitors of matrix metalloproteinases. Drug Resist. Updates 2004, 7, 195-208.

79. Mannello, F.; Tonti, G.; Papa, S. Matrix metalloproteinase inhibitors as anticancer therapeutics. Curr. Cancer Drug Targets 2005, 5, 285-298.

80. Gialeli, C.; Theocharis, A.D.; Karamanos, N.K. Roles of matrix metalloproteinases in cancer progression and their pharmacological targeting. FEBS J. 2011, 278, 16-27.

81. Lokeshwar, B.L.; Escatel, E.; Zhu, B. Cytotoxic activity and inhibition of tumor cell invasion by derivatives of a chemically modified tetracycline CMT-3 (COL-3). Curr. Med. Chem. 2001, 8 , 271-279.

82. Tolomeo, M.; Simoni, D. Drug resistance and apoptosis in cancer treatment: Development of new apoptosis-inducing agents active in drug resistant malignancies. Curr. Med. Chem. Anticancer Agents 2002, 2, 387-401.

83. Lokeshwar, B.L. Chemically modified non-antimicrobial tetracyclines are multifunctional drugs against advanced cancers. Pharmacol. Res. 2011, 63, 146-150.

84. Richards, C.; Pantanowitz, L.; Dezube, B.J. Antimicrobial and non-antimicrobial tetracyclines in human cancer trials. Pharmacol. Res. 2011, 63, 151-156.

85. Konstantinopoulos, P.A.; Karamouzis, M.V.; Papatsoris, A.G.; Papavassiliou, A.G. Matrix metalloproteinase inhibitors as anticancer agents. Int. J. Biochem. Cell Biol. 2008, 40, 1156-1168.

86. Curci, J.A.; Mao, D.; Bohner, D.G.; Allen, B.T.; Rubin, B.G.; Reilly, J.M.; Sicard, G.A.; Thompson, R.W. Preoperative treatment with doxycycline reduces aortic wall expression and activation of matrix metalloproteinases in patients with abdominal aortic aneurysms. J. Vasc. Surg. 2000, 31, 325-342.

87. Prall, A.K.; Longo, G.M.; Mayhan, W.G.; Waltke, E.A.; Fleckten, B.; Thompson, R.W.; Baxter, B.T. Doxycycline in patients with abdominal aortic aneurysms and in mice: Comparison of serum levels and effect on aneurysm growth in mice. J. Vasc. Surg. 2002, 35, 923-929.

88. Baxter, B.T. Abdominal aortic aneurysm regression by medical treatment: Possibility or pipe dream? J. Vasc. Surg. 2006, 43, 1068-1069.

89. Xiong, W.; Knispel, R.A.; Dietz, H.C.; Ramirez, F.; Baxter, B.T. Doxycycline delays aneurysm rupture in a mouse model of Marfan syndrome. J. Vasc. Surg. 2008, 47, 166-172.

90. Petrinec, D.; Liao, S.; Holmes, D.R.; Reilly, J.M.; Parks, W.C.; Thompson, R.W. Doxycycline inhibition of aneurysmal degeneration in an elastase-induced rat model of abdominal aortic aneurysm: Preservation of aortic elastin associated with suppressed production of $92 \mathrm{kD}$ gelatinase. J. Vasc. Surg. 1996, 23, 336-346.

91. Boyle, J.R.; McDermott, E.; Crowther, M.; Wills, A.D.; Bell, P.R.; Thompson, M.M. Doxycycline inhibits elastin degradation and reduces metalloproteinase activity in a model of aneurysmal disease. J. Vasc. Surg. 1998, 27, 354-361. 
92. Curci, J.A.; Petrinec, D.; Liao, S.; Golub, L.M.; Thompson, R.W. Pharmacologic suppression of experimental abdominal aortic aneurysms: A comparison of doxycycline and four chemically modified tetracyclines. J. Vasc. Surg. 1998, 28, 1082-1093.

93. Manning, M.W.; Cassis, L.A.; Daugherty, A. Differential effects of doxycycline, a broad-spectrum matrix metalloproteinase inhibitor, on angiotensin II-induced atherosclerosis and abdominal aortic aneurysms. Arterioscler. Thromb. Vasc. Biol. 2003, 23, 483-488.

94. Sho, E.; Chu, J.; Sho, M.; Fernandes, B.; Judd, D.; Ganesan, P.; Kimura, H.; Dalman, R.L. Continuous periaortic infusion improves doxycycline efficacy in experimental aortic aneurysms. J. Vasc. Surg. 2004, 39, 1312-1321.

95. Bartoli, M.A.; Parodi, F.E.; Chu, J.; Pagano, M.B.; Mao, D.; Baxter, B.T.; Buckley, C.; Ennis, T.L.; Thompson, R.W. Localized administration of doxycycline suppresses aortic dilatation in an experimental mouse model of abdominal aortic aneurysm. Ann. Vasc. Surg. 2006, 20, 228-236.

96. Xie, X.; Lu, H.; Moorleghen, J.J.; Howatt, D.A.; Rateri, D.L.; Cassis, L.A.; Daugherty, A. Doxycycline does not influence established abdominal aortic aneurisms in angiotensin II-infused mice. PLoS ONE 2012, 7, e46411.

97. Sivaraman, B.; Ramamurthi, A. Multifunctional nanoparticles for doxycycline delivery towards localized elastic matrix stabilization and regenerative repair. Acta Biomater. 2013, 9, 6511-6525.

98. Bettany, J.T.; Peet, N.M.; Wolowacz, R.G.; Skerry, T.M.; Grabowski, P.S. Tetracyclines induce apoptosis in osteoclasts. Bone 2000, 27, 75-80.

99. Thompson, R.W.; Baxter, B.T. MMP inhibition in abdominal aortic aneurysms: Rationale for a prospective randomized clinical trial. Ann. N. Y. Acad. Sci. 1999, 878, 159-178.

100. Mosorin, M.; Juvonen, J.; Biancari, F.; Satta, J.; Surcel, H.M.; Leinonen, M.; Saikku, P.; Juvonen, T. Use of doxycycline to decrease the growth rate of abdominal aortic aneurysms: A randomized, double-blind, placebo-controlled pilot study. J. Vasc. Surg. 2001, 34, 606-610.

101. Baxter, B.T.; Pearce, W.H.; Waltke, E.A.; Littooy, F.N.; Hallett, J.W., Jr.; Kent, K.C.; Upchurch, G.R., Jr.; Chaikof, E.L.; Mills, J.L.; Fleckten, B.; et al. Prolonged administration of doxycycline in patients with small asymptomatic abdominal aortic aneurysms: Report of a prospective (Phase II) multicenter study. J. Vasc. Surg. 2002, 36, 1-12.

102. Brown, D.L.; Desai, K.K.; Vakili, B.A.; Nouneh, C.; Lee, H.M.; Golub, L.M. Clinical and biochemical results of the metalloproteinase inhibition with subantimicrobial doses of doxycycline to prevent acute coronary syndromes (MIDAS) pilot trial. Arterioscler. Thromb. Vasc. Biol. 2004, 24, 733-738.

103. Meijer, C.A.; Stijnen, T.; Wasser, M.N.J.M.; Hamming, J.F.; van Bockel, J.H.; Lindeman, J.H.N. Doxycycline for stabilization of abdominal aortic aneurysms: A randomized trial. Ann. Intern. Med. 2013, 159, 815-823.

104. ClinicalTrails.gov Identifier: NCT01756833. Available online: https://www.clinicaltrails.gov/ show/NCT01756833 (accessed on 27 November 2014).

105. Gu, Y.; Walker, C.; Ryan, M.E.; Payne, J.B.; Golub, L.M. Non-antibacterial tetracycline formulations: Clinical applications in dentistry and medicine. J. Oral Microbiol. 2012, 4, 19227.

106. Cunha, B.A.; Comer, J.B.; Jonas, M. The tetracyclines. Med. Clin. N. Am. 1982, 66, 293-302.

107. Welling, P.G.; Koch, P.A.; Lau, C.C.; Craig, W.A. Bioavailability of tetracycline and doxycycline in fasted and nonfasted subjects. Antimicrob. Agents Chemother. 1977, 11, 462-469. 
108. Van den Bogert, C.; van Kernebeek, G.; de Leij, L.; Kroon A.M. Inhibition of mitochondrial protein synthesis leads to proliferation arrest in the $\mathrm{G}_{1}$-phase of the cell cycle. Cancer Lett. 1986, $32,41-51$.

109. Ogrinc, K.; Logar, M.; Lotrič-Furlan, S.; Cerar, D.; Ružić-Sabljic, E.; Strle, F. Doxycycline versus ceftriaxone for the treatment of patients with chronic Lyme borreliosis. Wien. Klin. Wochenschr. 2006, 118, 696-701.

110. Ljøstad, U.; Skogvoll, E.; Eikeland, R.; Midgard, R.; Skarpaas, T.; Berg, A.; Mygland, A. Oral doxycycline versus intravenous ceftriaxone for European Lyme neuroborreliosis: A multicentre, non-inferiority, double-blind, randomised trial. Lancet Neurol. 2008, 7, 690-695.

111. Borg, R.; Dotevall, L.; Hagberg, L.; Maraspin, V.; Lotric-Furlan, S.; Cimperman, J.; Strle, F. Intravenous ceftriaxone compared with oral doxycycline for the treatment of Lyme neuroborreliosis. Scand. J. Infect. Dis. 2005, 37, 449-454.

(C) 2015 by the authors; licensee MDPI, Basel, Switzerland. This article is an open access article distributed under the terms and conditions of the Creative Commons Attribution license (http://creativecommons.org/licenses/by/4.0/). 